\title{
Unamuno's Late Reading of Shakespeare: Civil War and Folly
}

\author{
GARETH WOOD \\ University College London
}

This article is based on research recently undertaken in the Casa-Museo Miguel de Unamuno in Salamanca, research that I began in the hope of reaching a better understanding of why Unamuno lent his support to the Nationalist coup that started the Spanish Civil War. His decision to do so tarnished the reputation of a public intellectual who had devoted most of his adult life to tireless commentary on Spain's imperfect Restoration political system and even endured six years of self-imposed exile in protest at the dictatorship of Primo de Rivera. ${ }^{1}$ Unamuno is famously remembered for the rebuke he delivered to Franco's General Millán Astray and an audience of fervent Falangist supporters in the ceremonial hall of Salamanca University on 'el día de la raza', 12 October 1936: 'Venceréis pero no convenceréis', offering in the process what time would show to be a prophetic encapsulation of the Spanish Right's illegitimacy and intellectual aridity. ${ }^{2}$ What is less often pointed out is that Unamuno's censure was all the more unexpected because he had welcomed Mola's coup as a necessary corrective to the, in his eyes, wayward Frente Popular government led by Manuel Azaña. During the course of the research I undertook, I became aware that in the final months of his life, and more particularly during his final summer, Unamuno reread at least seven of Shakespeare's plays: the three parts of King Henry VI, The Tragedy of King Richard II, King Richard III, King Lear and The Tempest. I further learned that the references to Shakespeare in Unamuno's final political writings and in the notes he was making on the causes of the Civil War, published as El resentimiento trágico de la vida. Notas sobre la

1 I use the designation 'public intellectual' in deference to Stephen G. H. Roberts' superb study of Unamuno's forging of the role of the intellectual in modern Spain, Miguel de Unamuno o la creación del intelectual moderno español (Salamanca: Univ. de Salamanca, 2007).

2 For a recent example, see Antony Beevor, The Battle for Spain: The Spanish Civil War 1936-1939 (London: Weidenfeld and Nicolson, 2006), 100-01. 
revolución y guerra civil españolas (hence El resentimiento), have attracted little or no comment from either the original editor who prepared those notes for publication or more recent Unamuno scholars.

This article will therefore develop two strands of argument in parallel, the first an account of why Unamuno supported the Nationalist coup, the second an analysis of how his late re-engagement with Shakespeare can illuminate that account. While developing the first of these strands I shall be standing on the shoulders of a number of recent scholars whose work has served to elucidate Unamuno's views on the Civil War, among them Elías Díaz, Carlos Feal, Luciano González Egido, Eduardo Pascual Mezquita, Colette and Jean-Claude Rabaté, Stephen Roberts, and Mercedes Tasende. When it comes to addressing Unamuno's reading of Shakespeare, save for an illuminating overview by Roberts, there is little previous research on which to draw, hence the archival and analytical work is very much my own. What we shall see is that the references to Shakespeare in Unamuno's late political writings go to the heart of his understanding of the Civil War as it developed over the final months of his life. To do so we shall compare his explicit comments on Shakespeare with the annotations he made in his editions of Shakespeare's plays, and from there expand on what in his final writings are often highly compressed observations. ${ }^{3}$ (My reading has revealed the surprising fact that, in spite of its being on record since at least the 1960s that Unamuno's editions of Shakespeare were annotated and available for consultation, to date no research has been published on them. $)^{4}$

Unamuno owned, read and annotated the four-volume Works of William Shakespeare edited by Howard Staunton (London: Routledge, Warne \& Routledge, 1864). The first piece of useful information to be gleaned from his copies is the extent of his knowledge of the bard. He was in the habit of drawing horizontal lines on the contents pages of his books next to the titles of the essays, plays, poems or stories he had read. From the contents pages of the Staunton editions we gather that he had read the following plays (listed by volume): Vol. 1: The Two Gentlemen of Verona, Love's Labour's Lost,

3 According to Mercedes Tasende, the notes that make up El resentimiento form 'una serie interrumpida y fragmentaria de instantáneas relacionadas con la guerra que, animadas por una polifonía de voces, captan la intensidad de la situación vivida por los españoles y acaban formando un documental de la tragedia que está asolando a España' ('El resentimiento trágico de la vida: últimas reflexiones de Unamuno en torno a la guerra civil española', Anales de la Literatura Española Contemporánea, 34:1 [2009], 275-304 [p. 279]).

4 Gustav Ungerer, 'Unamuno and Shakespeare', in Pensamiento y Letras en la España del siglo XX: Congreso Internacional en Vanderbilt University para celebrar el centenario de Miguel de Unamuno 1864-1964, ed. Germán Bleiberg and E. Inman Fox (Nashville: Vanderbilt U. P., 1966), 513-32 (pp. 515-16). Ungerer gives Manuel García Blanco as the source of the information, though does not cite a reference. Ungerer's article now appears somewhat dated both in its tendency to make sweeping generalizations about Unamuno's and Shakespeare's 'Art' but also because so much new material both by and on Unamuno has come to light since the mid 1960 s, including of course El resentimiento itself. 
Romeo and Juliet, The Taming of the Shrew, King John, A Midsummer Night's Dream, The Merchant of Venice, The Tragedy of King Richard II, King Henry IV Part I; Vol. 2: King Henry IV Part 2, The Merry Wives of Windsor, Much Ado About Nothing, All's Well that Ends Well, King Henry V, As You Like It, Pericles, Twelfth Night, King Henry VI Parts I, II \& III; Vol. 3: Timon of Athens, King Richard III, Measure for Measure, King Henry VIII, Cymbeline, The Tempest, King Lear, The Winter's Tale; Vol. 4: Troilus and Cressida, Hamlet, Julius Caesar, Macbeth, Antony and Cleopatra, and Othello. Of greater interest for our present purposes are his marginal annotations, which usually take the form of underlinings of unfamiliar vocabulary and lines drawn against particular passages. ${ }^{5}$

Before looking in more detail at Unamuno's engagement with Shakespeare and the light it sheds on his views of the Civil War, I wish briefly to digress and argue for the relevance of these enquiries. To do so, I will set them alongside the modern phenomenon that has been dubbed the 'Historical Memory' movement, as a way of highlighting why Unamuno's views remain pertinent today. In fact, I would argue that the tenor of recent debates in Spain about the Civil War and dictatorship periods makes an awareness of the depth and difficulty of the dilemma faced by Unamuno in 1936 all the more salutary. As John Butt has put it, Unamuno's plight 'perfectly expresses the impossible situation faced by thousands of thoughtful Spaniards'. ${ }^{6}$

Even the most casual observers of public life in Spain cannot have failed to notice that the last decade has seen an intensification of the debate on how best to remember the country's troubled twentieth-century history. Politicians, cultural commentators, polemicists, novelists and journalists in both the print and visual media have contributed to a wide-ranging and fractious discussion of how the dead of the Civil War and Franco's dictatorship period should be commemorated. ${ }^{7}$ The 2007 'Ley por la que se reconocen y amplían derechos y se establecen medidas a favor de quienes padecieron persecución o violencia durante la Guerra Civil y la dictadura', more punchily known as the 'Ley de Memoria Histórica' in the Spanish press, paved the way for the relatives of Civil War victims to disinter mass graves and give their dead a dignified

5 It is regrettably the case that we cannot know when Unamuno annotated his editions of Shakespeare. This article will do its utmost to demonstrate through textual evidence a continuity between his annotations and the passages he cites in his late political writings. Where those continuities cannot be traced, more speculative interpretation will be offered, while making clear that that is what it is.

6 John Butt, 'Spain's Great Divide', Times Literary Supplement, 3 August 2007, pp. 5, 7-8 (p. 7).

7 For three good introductions, among many, to the issues at stake, see Jo Labanyi, 'The Language of Silence: Historical Memory, Generational Transmission and Witnessing in Contemporary Spain', Journal of Romance Studies, 9:3 (2009), 23-35; Jeremy Treglown, “ “A Heartless Craft”: Spain's History Wars', The Dublin Review, 28 (2007), 34-56; Giles Tremlett, Ghosts of Spain (London: Faber and Faber, 2006), 3-95. 
burial. It further made provision for the elimination of the last vestiges of Franco's dictatorship by renaming streets bearing the titles of either the 'Generalísimo' or figures associated with his regime, as well as removing public memorials to the 'glorious dead' of the Nationalist side. Central to the continuing debate have been disputes over responsibility for the outbreak of the war itself. In one corner stands a figure like Pío Moa, who argues that the Civil War in fact began with the left-wing uprising in Asturias in October 1934 and that Mola's coup of July 1936 was no more than a pre-emptive strike against an imminent Communist revolution. In the other stand historians of international reputation, among them Santos Juliá and Paul Preston, for whom the Nationalist revolt was an unjustifiable attack on a democratically elected government. The blame over which side of Spain's political divide bears greater responsibility for the outbreak of war has occupied thousands of column inches in the country's daily press in recent years. At stake are the respective roles of victim and aggressor and the moral and political capital that go with them.

Central to these debates have been disagreements over the nature of the Second Republic and Azaña's Frente Popular government. Voted into power in February 1936, Azaña's coalition of the Left sought to pick up the modernizing agenda that the electoral victory of the Right in November 1933 had interrupted; an agenda that included the secularization of education, more equitable distribution of agricultural land among the peasantry, the extension of suffrage, provision for divorce, and greater autonomy for Spain's linguistically distinct regions. Consensus has yet to be reached about precisely what went wrong for Azaña in the months leading up to Mola's coup. According to some the pace of change was too slow and Spain's increasingly powerful Left began to flex its muscles in frustration, while more traditionalist elements wondered what their country would look like by the time this raft of radical proposals had become law. The Second Republic had made itself powerful enemies in its short life by shrinking the size of the country's army and sending its most reactionary generals to far-flung outposts, where, it was hoped, they could do least damage (hence why the start of the Civil War found General Franco in Morocco, having flown there from Las Palmas de Gran Canaria); it had upset the Church, aristocracy and new industrialists by creating a climate in which their dominant position at the top of society was under threat from secular educators, peasant farmers, and trade unions respectively. Others would argue that Azaña's government had simply lost control of the workers' and anarchist groups that were responsible for the civil unrest, church burning and attacks on priests and nuns that escalated in the Spring of 1936; that it failed in its first duty to the Spanish electorate, to keep them safe.

Significant contributors to this debate have been Spain's contemporary novelists. Almudena Grandes has pledged to take up the mantle left by Benito Pérez Galdós by writing a new series of 'Episodios Nacionales', 
entitled 'Episodios de una guerra interminable', set during the conflict and postwar periods, the first of which, Inés y la alegría, appeared in 2010. Her 2007 novel El corazón helado tells the story of the betrayal suffered by a Republican exile at the hands of an unscrupulous Nationalist soldier who manages to pass himself off as a political ally. What characterizes her novel above all is its steadfast refusal to give any political or moral legitimacy to the Nationalist cause: the Republican exile is as decent, honest, hardworking and warm as the Nationalist soldier is devious, cruel, ruthless and callous. Ignacio Martínez de Pisón's novel Dientes de leche deals in similarly facile and Manichaean terms with that same political divide. At the other end of the spectrum, meanwhile, the conservative writer Juan Manuel de Prada published in 2007 his novel El séptimo velo in which the moral compromises of the radical Left are painted as the greatest threat to life and liberty in both Spain's Civil War and the Second World War. The response to this new genre of Historical Memory fiction has been overwhelming: $E l$ corazón helado topped Spain's best-seller lists for many months, shifting hundreds of thousands of copies, as well as winning the Premio Fundación Lara and the 2007 Libro del Año awarded by Madrid's booksellers, ${ }^{8}$ while $E l$ séptimo velo won the Seix Barral Premio Biblioteca Breve. That the tendency of these novels to deal in unhelpfully polarized or simplistic versions of Spain's recent past is making at least some people uneasy can be shown by the reaction of the novelist Antonio Muñoz Molina. He felt moved to introduce his own attempt to depict the Second Republic through fiction, La noche de los tiempos (2009), with a warning that '[las] categorías abstractas [...] son muy tranquilizadoras porque nos permiten sentirnos épicos retrospectivamente'. ${ }^{9}$ When presenting his novel he criticized the tendency to talk about the Second Republic as if it had been the promised land, something he believed to be neither historically accurate nor intellectually helpful. His words were echoed by the critic Jo Labanyi who has suggested that the Historical Memory genre risks creating 'a culture of victimhood, rather than examining the very modern political lessons of the Spanish Republic'. ${ }^{10}$

While I do not wish to deny the value that Grandes' and Martínez de Pisón's novels may have in giving a voice to the sufferings of a large

8 There is also anecdotal evidence of the book's success at the Madrid Feria del Libro, where a permanently long queue of readers formed in front of the stall in which Grandes was signing copies of her novel. See I. S. R., 'La Feria del Libro cierra sus puertas con éxito de ventas y público', $A B C$, 11 June 2007, p. 79.

9 Juan Carlos Galindo, 'Muñoz Molina alerta sobre la complejidad de juzgar y conocer el pasado', El País, 23 September 2010, <http://www.elpais.com/articulo/cultura/Munoz/ Molina/alerta/complejidad/juzgar/conocer/pasado/elpepucul/20100923elpepucul_16/Tes> (accessed February 2011).

10 Jo Labanyi, Spanish Literature: A Very Short Introduction (Oxford: Oxford U. P., 2010), 74 . 
Republican and exiled community, what I do suggest is that a historically and ethically coherent approach to these matters requires more balance. There are of course novelists in Spain whose approach to the Civil War admits of greater nuance, obvious examples of whom would include Javier Cercas, Javier Marías, Eduardo Mendoza, the aforementioned Muñoz Molina and Isaac Rosa. However, given the prevalence, noted by Labanyi, of a tendency to oversimplify, it remains my contention that one way of providing greater balance is to remind ourselves of the agonizing choice faced by many Spaniards at the war's outset, one of whom, Miguel de Unamuno, has left ample testimony of that very dilemma.

He had returned to his beloved Salamanca in February 1930, fourteen months before the declaration of the Second Republic, after six painful years of self-imposed exile. What had been his difficult separation from a public who remained his principal spiritual preoccupation was at an end, leaving him once more able to take up his pen in commentary on his country's political and social development. Exactly six years later the panorama could hardly have been bleaker. Although early 1936 found the Rector of Salamanca in England on a round of visits to the Universities of London, Oxford and Cambridge, each of which awarded him an honorary doctorate, he was close to being a broken man. As befitted such formal occasions, Unamuno was able to address audiences at both King's College London and Oxford University to acknowledge their generosity. Characteristically, he also used the opportunity to assess Spain's current political climate. The reports on his speeches that found their way into the Spanish press record the impassioned concerns of a man who had begun to see civil war in his homeland as an inevitability. Addressing the student body in London, he could not help his mind flying back to the youth of Spain, who, even as he spoke, were massing on either side of a noxious political divide:

No hemos sabido asomarnos al alma de la mocedad española, y esa juventud, hoy, es masa que sigue a los energúmenos de ambos lados, que predican y encienden la guerra civil. Yo me he negado ya a hablar en público en España, porque ahora nadie oye allí a nadie. El español ha confundido el gesto con el esfuerzo. Unos saludan así [Communist salute, fist raised] y otros saludan así [Roman salute, arm outstretched]. Y España se hunde. ${ }^{11}$

The correspondent who wrote up the account of Unamuno's speech in Oxford was forced to report that the audience had been left baffled by the Spaniard's sombre and disjointed address: 'En el salón flotaba un silencio penoso, de compasión, incomprensión y desprecio, que sólo de vez en cuando

11 Eduardo Pascual Mezquita, La política del último Unamuno (Salamanca: Anthema, 2003), 365. 
venía a romper el cristal de una risa femenina'. ${ }^{12}$ The late Sir Peter Russell, who was present in Oxford at Unamuno's investiture and the subsequent dinner, recalled that he appeared beleaguered, depressed by and despairing of his country's seemingly inevitable slide into civil conflict. One further thing to emerge from his visit was that, despite having translated Herbert Spencer into Spanish and read among others Sir Thomas Browne, Byron, Carlyle, Poe and Shakespeare in English, Unamuno's spoken command of the language was anything but fluent. His hosts were obliged to ensure that he was surrounded by Spanish speakers at all times since his attempts at sustaining a conversation in English proved fruitless. ${ }^{13}$

This picture of an apprehensive, even disconsolate Unamuno was thrown into sharp relief five months later when, to the disgust of many of his fellow citizens, he gave his support to the Nationalist coup that started the Spanish Civil War. For so long the mainstay of liberal opinion in Spain and the scourge of the dictatorial tendencies of Alfonso XIII and Primo de Rivera, his behaviour was so out of character that the Madrid newspaper El Sindicalista concluded quite simply that Unamuno had lost his mind. ${ }^{14}$ Nor was the fear of insanity far from the author's own thoughts. An unpublished article from the late summer of 1936 unearthed and published by Pascual Mezquita shows Unamuno struggling with the fear of madness, just as King Lear does in the eponymous play:

Estaba releyendo El rey Lear, y al llegar a aquello de: ‘No me dejes volverme loco, no loco dulce cielo!; ¡mantenme sereno!; ¡no querría volverme loco!' Al llegar a esto, tuve que detenerme. Porque yo, que he acusado a mis compatriotas de haberse vuelto locos, siento que me envuelve su locura, que se me está criando mala sangre. Con un poder de aborrecimiento, de tirria, de rencor, de que no me creía capaz. ${ }^{15}$

The lines he translates here are indeed marked in the margin of his edition of the play: 'O let me not be mad, not mad, sweet heaven! I would

12 Mezquita, La politica, 368. This write-up from an anonymous correspondent of the newspaper Acción Española seems particularly severe in its criticism of the ageing Unamuno, especially in its unnecessary use of 'desprecio' to describe the audience's reaction to his speech.

13 Russell recalled these events during a graduate seminar convened by the sub-Faculty of Spanish at the University of Oxford. The event, entitled 'Recollections of the Second Republic', took the form of an interview with Dr Xon de Ros. A recording of the proceedings is stored in the Taylorian Library in Oxford. Unamuno's most recent biographers, Colette and Jean-Claude Rabaté, seem to have had access to Russell's recollections since they refer to 'un catedrático de Oxford' who described Unamuno's sombre demeanour and poor grasp of spoken English. See their Miguel de Unamuno: biografía (Madrid: Taurus, 2009), 660.

14 Luciano González Egido, Agonizar en Salamanca: Unamuno, julio-diciembre de 1936, rev. ed. (Barcelona: Tusquets, 2006), 73-74.

15 Mezquita, La política, 386. 
not be mad. Keep me in temper, I would not be mad'. ${ }^{16}$ Coming as they do towards the end of the first Act, the King's words have been variously interpreted as 'an ironic moment of lucidity for a Lear already mad, or [...] a terrible premonition for a still sane Lear of what is shortly to come'. ${ }^{17}$ In a few short and ill-judged moments of distemper the King has renounced his crown, disowned his favourite daughter, and sent his most faithful servant into exile for life. Whether premonition or confirmation of insanity, his words evidently resonated with an Unamuno who was himself increasingly isolated ideologically and physically from both compatriots and family. ${ }^{18}$ Like the ageing Lear, he began to suspect that that isolation was more of his own doing than he might have cared to admit.

The particular lunacy Unamuno fears is evidently the madness of collective savagery that has overtaken his compatriots. Yet this passage cannot but recall another period of self-doubt, his time in exile, captured in Cómo se hace una novela, when he worried that his stance against Primo de Rivera placed him so at odds with public opinion that he began to fear for his reason:

Estar loco se dice que es haber perdido la razón. La razón, pero no la verdad, porque hay locos que dicen las verdades que los demás callan por no ser ni racional ni razonable decirlas, y por eso se dice que están locos. ¿Y qué es la razón? La razón es aquello en que estamos todos de acuerdo, todos o por lo menos la mayoría. ${ }^{19}$

Another of the marked passages in his edition of King Lear is that early in the play in which Kent observes that 'Freedom lives hence and banishment is here', perhaps because it brought to mind his own prolonged exile. ${ }^{20}$ Just as in 1936 he was seeking 'huelgo espiritual en la relectura y remeditación de las tempestuosas tragedias shakespearianas', during his exile, that most trying period of his adult life, he had also turned to Shakespeare for solace, as a letter to José Bergamín from Hendaye in 1926 attests:

Estoy releyendo a Shakespeare. Y el otro día me hirió el relato que de la muerte de Sir John Falstaff hace Mistress Quickly en la escena III del acto II del 'Rey Enrique V'. Cuando la gran alcahueta le decía a Falstaff moribundo que no pensara en Dios y se lo decía para consolarle: 'to

16 William Shakespeare, King Lear, ed., with an intro., by R. A Foakes (London: Arden, 2003), 1.5.43-45.

17 Shakespeare, King Lear, 215.

18 The outbreak of war found two of Unamuno's sons, as well as his son-in-law, in Madrid. Unamuno's correspondence attests to his fears for their well-being in late 1936.

19 Miguel de Unamuno, Cómo se hace una novela, ed. Teresa Gómez Trueba (Madrid: Cátedra, 2009), 147.

20 Shakespeare, King Lear, 1.1.182. 
comfort him'. Y comparé la muerte de Falstaff con la de Don Quijote. Y con la muerte civil de España a la que para consolarla [se] le dice que no piense en la justicia. ${ }^{21}$

The parallel he draws between Mistress Quickly's attempts to console the dying Falstaff at the risk of damning his soul to Hell and the desire to keep from Spanish minds, at the risk of infantilizing them, all thoughts of justice is clear and forceful.

We find an analogous further recourse to King Lear in the final part of the unpublished article quoted above:

Y seguí leyendo, a modo de desesperado consuelo, la tragedia, y llegué a lo de Gloucester cuando dice [...] 'Como las moscas para los niños traviesos, igual para los dioses: ¡nos matan por juego!' Y recordé cómo de niño me divertía atormentando moscas, tal como hoy se divierte mi nieto. ¿Y los dioses de Gloucester? o mejor, ¿de Shakespeare? ¿Qué terrible y juguetona divinidad shakespeariana se está divirtiendo ahora con nosotros, los españoles, lanzándonos a los unos contra los otros? ${ }^{22}$

What is clear is that Shakespeare is providing him with a set of reference points on which to hang his developing thoughts. On this occasion those thoughts take the form of an utter despair, the kind of all-encompassing, cosmic solitude that Lear and Gloucester come increasingly to feel, culminating in the latter's attempted suicide. And yet, perhaps Gloucester's words represent a form of hopeless consolation for Unamuno: belief in a higher power whose playthings Spaniards are robs them momentarily of agency and responsibility. Were it to be the case that Spain's Civil War had simply been ordained from on high by a despotic and inscrutable god, at least Unamuno would be saved the task of tracking down its causes. But he does not believe that, and instead turns next to The Tempest:

Y allí en aquella fantasía estupenda me encontré con Caliban, el hombre tierra, el hombre masa, el monstruo... (Larra escribió sobre el hombre globo, gaseoso, espiritual, y sobre el hombre líquido - la clase media - que produce inundaciones, y sobre el hombre térreo que estalla en terremotos) Caliban, a quien Próspero le enseñó a hablar, le dio el opio de la palabra para adormecerle y domarle, y luego Stéfano, el mayordomo borracho, le emborrachó con otras palabras, con alcohol de tópicos materiales hasta hacerle exclamar: 'Libertad, jolé!, jolé!; libertad, libertad, ¡olé!, libertad'. [...] Aquel pobre Caliban, bamboleándose entre el opio y el alcohol: ¡El

21 El epistolario José Bergamín-Miguel de Unamuno (1923-1935), ed. and notes by Nigel Dennis (Valencia: Pre-Textos, 1993), 59.

22 Mezquita, La política, 387. 
opio oriental de la resignación nirvanática y el alcohol occidental de la mentida rebeldía revolucionaria, Caliban $!^{23}$

Unamuno is quoting Larra's article 'El hombre globo', where Larra does indeed characterize the working classes as being made of earth, the lowest element in the classical schema. For Unamuno, Caliban represents mankind in his savage aspect, evoking the return to untutored primitivism and rejection of Christian civilization that he felt characterized so many Spanish working-class men and women in the early months of 1936 . His description of Caliban caught between two stools, the opium-induced Nirvana of resignation and the Western alcohol of trumped-up revolutionary rebellion, neither of which he properly understands, is not unproblematic. Its tone hints at a paternalism or simple exasperation that can be found elsewhere in Unamuno's writings of this period. ${ }^{24}$

A letter he wrote in April 1936 describes the spectacle offered by a participant in that year's Holy Week processions in Seville, who emerged from beneath the float he was carrying to issue the following challenge: 'soy comunista pero al que falte a mi Virgen le mato'. Not unnaturally, Unamuno concluded that 'el pobre hombre ni sabe lo que es comunismo ni lo que es religión cristiana' and went on to expand on the theme, describing an encounter with 'un pobre tonto' who asked him if he still believed that God exists. ${ }^{25}$ Rather than offer a straight reply, he explained that for him to answer the question they would have first to agree on what they each understood by 'God', 'exists' and 'believe'. ${ }^{26}$ We should bear in mind that these sentiments are expressed in the privacy of an unpublished article and a personal letter but should not resist the insights they offer into his exasperation at what he saw as the underdeveloped spiritual and political awareness of his fellow citizens. In his edition of Shakespeare, one of only five marked passages from The Tempest is Caliban's rebuke to Miranda in Act II: 'You taught me language, and my profit on't / Is I know how to curse. The red plague rid you / For learning me your language'. ${ }^{27}$ The sorry use to which Caliban puts his linguistic skill seems to have mirrored in Unamuno's mind his countrymen's adoption of their new-found political freedoms: that

23 Mezquita, La política, 387-88.

24 Martin Nozick suggests that Unamuno's attitude to the masses throughout his career was characterized by an alternation between 'tenderness and contempt': 'The sleeping giant [the people] elicits from him reactions ranging from rêverie and nostalgia on the one hand to optimistic expectation on the other, but when it bestirs itself, it brings down on its head his wrath and fustigation'. See his 'Unamuno and the Second Spanish Republic', in Pensamiento y Letras en la España del siglo XX, ed. Bleiberg and Fox, 379-93 (p. 381).

25 Miguel de Unamuno, Epistolario inédito, ed., intro. and notes by Laureano Robles, 2 vols (Madrid: Espasa-Calpe, 1991), II [1915-1936], 342.

26 Unamuno, Epistolario inédito, ed. Robles, II, 343-44.

27 William Shakespeare, The Tempest, ed., with an intro., by Virginia Mason Vaughan and Alden T. Vaughan (London: Arden, 2003), 1.2.364-66. 
they used them above all to insult, belittle and alienate one another, hence his increasing tendency in his final political writings to refer to [sic] 'los hunos y los hotros'. We shall not know whether Caliban's use of the phrase 'red plague' struck Unamuno as bitterly appropriate, given the Communist banner under which so many in Spain now marched, but it is not unlikely.

Although in the days immediately following Mola's coup Unamuno made a point of maintaining the routines that had underpinned a lifetime in Salamanca, sitting out on the terrace of his regular haunt, the Café Novelty on the Plaza Mayor, visiting the 'casino' of which he was honorary president, he realized that all was not well when colleagues and friends started disappearing from their homes. ${ }^{28}$ References in El resentimiento to what Unamuno saw as the 'civilized' Carlist wars he witnessed in the Bilbao of his childhood 'reflejan', as Mercedes Tasende rightly puts it, 'un sentimiento generalizado entre muchos españoles criados entre pronunciamientos': the conviction that the Nationalists would offer no more than a palliative readjustment to the wayward government while giving it stability in the face of widespread public disorder. ${ }^{29}$ Before we scoff at their naïvety we should remember that many of the army officers in Salamanca who came out in support of the Nationalist coup did so while giving cries of "Viva la República!' and the Republican flag flew over the Ayuntamiento until late August 1936. As Tasende reminds us, Unamuno was far from alone in supporting this view:

tras las elecciones de 1936, llegará a la conclusión de que la única forma de salvar la República es apoyando la operación de limpieza prometida por los generales golpistas, ignorando, como muchos contemporáneos suyos, que los militares iban a instaurar un régimen de terror que duraría cuatro décadas. No obstante, como advierte Cerezo Galán, el apoyo a los sublevados en julio del 36 de ningún modo debe interpretarse como una ruptura con el régimen republicano; a pesar de las diferencias con el régimen de Azaña, su compromiso con la República de signo liberal permanecería intacto. ${ }^{30}$

Such was Unamuno's conviction that Franco in particular represented a force for good that he contributed the considerable sum of 5,000 pesetas to the Nationalist war chest; equivalent to half the annual salary of a professor at Salamanca and a large amount for someone who was notoriously careful

28 González Egido, Agonizar en Salamanca, 48-50.

29 Elías Díaz, 'Unamuno y la Guerra Civil', in Actas del Congreso Internacional Cincuentenario de Unamuno. Universidad de Salamanca 10-20 diciembre 1986, ed. D. Gómez Molleda (Salamanca: Univ. de Salamanca, 1989), 17-27 (p. 21); Tasende, 'El resentimiento trágico de la vida: últimas reflexiones', 295.

30 Tasende, 'El resentimiento trágico de la vida: últimas reflexiones', 283. 
with his money. ${ }^{31}$ His verbal and financial support for the Nationalists caused the Republican government to revoke his lifelong appointment as Rector of Salamanca University on 22 August 1936 and rename the state secondary school in Bilbao that bore his name. ${ }^{32}$ In fact, Unamuno was only present in the Salamanca 'paraninfo' in October that year because Franco's Burgos government had reinstated him to the rectorship of the University in early September. ${ }^{33}$ His presence was intended to add gravitas and legitimacy to proceedings, a stratagem that backfired when the insults aimed by the thuggish Millán Astray at intellectuals, Basques and Catalans got Unamuno's blood up enough to provoke his uncompromising response.

Varying accounts exist of Unamuno's intervention. ${ }^{34}$ Although it has proved impossible to reach an absolute consensus on the content of his speech, we do at least have the notes he made during the course of proceedings to jog his memory when his turn came. The piece of paper on which he wrote is itself now a sadly moving artefact and can be seen on display in the Casa-Museo Unamuno. ${ }^{35}$ A moving artefact because Unamuno wrote his notes on the back of a letter he had received from the wife of a local protestant minister who had been arrested and imprisoned for being a freemason. Understandably, she had sought the help of as influential a figure as Unamuno, in hopes that he might intercede on her husband's behalf. Whether he had indeed been planning to raise the issue with the local Nationalist hierarchy and was hence carrying the letter with him to the 'paraninfo' we may never know, though it seems possible. His fragmented scribbles on the back of her letter also attest to their author's failing voice. The man who had been at the centre of political debate and public thought for four decades was running out of time to make his mark on the world. His notes in the 'paraninfo' are as fragmented as those he was taking at this period for $E l$ resentimiento and that, with a few poems, letters and interviews, were his final efforts towards understanding the terrible conflict that was to define his country for generations to come.

The price he paid for his outburst in the 'paraninfo' at Salamanca was partly professional since his lifelong appointment as Rector was brought to an end, but also personal. Franco's latter punishment was to impose an

31 Rabaté, Miguel de Unamuno: biografía, 673.

32 González Egido, Agonizar en Salamanca, 93-94.

33 González Egido, Agonizar en Salamanca, 101.

34 See for example, Unamuno's own brief account, Epistolario inédito, ed. Robles, II, 350; Rabaté, Miguel de Unamuno: biografía, 681-86; González Egido, Agonizar en Salamanca, 151-53. Hugh Thomas and Emilio Salcedo rely on the published account given by Luis Portillo, 'Unamuno's Last Lecture', in The Golden Horizon, ed. Cyril Connolly (London: University Books, 1953), 397-403. See Hugh Thomas, The Spanish Civil War (London: Eyre \& Spottiswoode, 1961), 353-55; Emilio Salcedo, Vida de don Miguel, $3^{\text {rd }}$ ed. (Salamanca: Anthema, [2005] [1 $1^{\text {st }}$ ed. 1964]), 470-72.

35 It is reproduced in Salcedo, Vida de don Miguel, 471. 
indefinite period of effective house arrest: 'effective' because, although Unamuno was free to move around Salamanca, he was tailed by a policeman wherever he went. He found the experience so unsettling and felt so sorry for the poor goon instructed to follow him that he opted to remain indoors. ${ }^{36}$ The image of Unamuno alone reading and empathizing too closely for comfort with King Lear and The Tempest, both plays about elderly, powerful men who come to rue their failure to wield authority judiciously, is not short on pathos. As Roberts suggests, Unamuno saw his final months of life refracted through Shakespeare's plays:

Es evidente que Shakespeare le habló directamente al alma durante esos últimos trágicos meses, y que Unamuno volvió una vez más a hacer suyas las palabras de Kierkegaard que había citado con tanta aprobación [...] ‘Fuera con ellos! Por eso se vuelve mi alma siempre al Antiguo Testamento y a Shakespeare. Allí se siente que es el hombre el que habla, allí se odia, allí se ama, se mata al enemigo, se maldice su descendencia por generaciones, allí se peca'. ${ }^{37}$

Luciano González Egido, who has written the most detailed account of Unamuno's final months, Agonizar en Salamanca, uses the opportunity to criticize his subject unsparingly for arrogance, naïvety, narcissism and stupidity. ${ }^{38}$ We are on territory where angels might fear to tread, since the assessment of Unamuno's actions implies an evaluation of his status as an ethical thinker and, more importantly, of the Second Republic itself. It is an easy task to beat him with the sticks provided by his mistakes but we need to ask how fruitful that exercise ultimately proves. Roberts, by contrast, describes Unamuno's final months of life as tragic. The word seems supremely appropriate and, given how careful a scholar Roberts is, not used lightly. So what is tragic about this vision of a defeated Unamuno, holed up in his house in Salamanca, reading plays like King Lear? I think the answer lies in the very definition of tragedy as Aristotle laid it down.

Firstly, the one fatal flaw that we might detect in Unamuno's character is his desire constantly to say or do what others least expected. As his foundation essay 'Soledad' (1905) reveals, he had an instinctive fear of grandstanding and hated the idea that he would ever become a simple crowdpleaser:

Nunca he sentido el deseo de conmover a una muchedumbre y de influir sobre una masa de personas que pierden su personalidad al amasarse, y

36 Unamuno refers to him as a 'pobre esclavo' (Epistolario inédito, ed. Robles, II, 350).

37 Stephen G. H. Roberts, 'Oyéndose casualmente a sí mismo: de Hamlet a Augusto Pérez', in Miguel de Unamuno: estudios sobre su obra, ed. Ana Chaguaceda Toledano (Salamanca: Univ. de Salamanca, 2003), 95-112.

38 See for example, González Egido, Agonizar en Salamanca, 49-50, 55, 83, passim. 
he sentido, en cambio, siempre furioso anhelo de mis hermanos en humanidad. Cuando he hablado en público he procurado casi siempre hacer oratoria lírica, y me he esforzado por forjarme la ilusión de que hablaba a uno solo de mis oyentes, a uno cualquiera, a cualquiera de ellos, a cada uno, no a todos en conjunto. ${ }^{39}$

It was with this principle in mind that he had taken the decision in late 1935 to stop making public speeches. Convinced that the whipped-up frenzy of mass gatherings prevented his hearers from listening to what he had to say, he wanted instead to reach the individual who read his newspaper or magazine articles in quiet contemplation. Throughout his career and to avoid the charge that he was anybody's stooge, he made rather too conspicuous a virtue of frustrating others' expectations of him. His desire to maintain a fierce independence and, chameleon-like, change his views from one day to the next, was, according to Roberts, precisely why he could not find a voice in the political climate of the Second Republic: 'En la República era necesario definirse y declararse, aliarse y alistarse [...] Tal situación dejaba menos espacio que antes para la voz del disidente no conformista'. ${ }^{40}$ The supreme example of this dangerously addictive trait was his unprecedented support for the Nationalists at the outset of the war. Interviewed in August 1936 he was still confident that his strategy of perpetual dissent would prove fruitful in the future:

Yo no estoy a la derecha ni a la izquierda. Yo no he cambiado. Es el régimen de Madrid el que ha cambiado. Cuando todo pase, estoy seguro de que yo, como siempre, me enfrentaré con los vencedores. ${ }^{41}$

History was, of course, to prevent this dream from becoming reality. ${ }^{42}$

Alongside this contrary character trait was his unwise advocacy of a form of figurative civil war. The theory, that had its most substantial outing in his novel Abel Sánchez, whereby the individual should seek to define himself in

39 Miguel de Unamuno, Obras completas, ed., intro. and notes by Manuel García Blanco, 9 vols (Madrid: Escelicer, 1966-1971), I: Paisajes y ensayos (1966), 1255.

40 Roberts, Miguel de Unamuno o la creación del intelectual moderno español, 227. Stanley Payne reaches the same conclusion. See his 'Unamuno's Politics', in Unamuno: Creator and Creation, ed. José Rubia Barcia and M. A. Zeitlin (Berkeley: Univ. of California Press, 1967), 203-19 (p. 215).

41 Mezquita, La política, 394.

42 According to one of Unamuno's young disciples, Julián Marías, and the writer Andrés Trapiello, Unamuno fell into precisely the same trap as many of his compatriots by allowing the extreme positions of Nationalists and loyalists to dominate the political agenda. What they should have been doing was giving a voice to more moderate opinion. See Julián Marías, España ante la historia y ante sí misma (1898-1936) (Madrid: Espasa-Calpe, 1996), 121; Andrés Trapiello, Las armas y las letras. Literatura y Guerra Civil (1936-1939), rev. ed. (Barcelona: Destino, 2010), 21. 
perpetual and fratricidal struggle with his fellow man, had become a cornerstone of his thinking. According to the theory neither individual should ever seek the destruction of their counterpart since that destruction would obliterate any sense of a self which depended for its boundaries on the presence of the other. Extraordinary though it might seem, Unamuno continued to propagate this idea into 1935, 'Guerra civil es la esencia de nuestro genio', when a more prudent strategy might have been to abandon such careless talk. ${ }^{43}$

The second aspect of Unamuno's situation that makes it tragic in the classical sense is that he was not too proud to admit two months later that he had made a terrible error of judgment. In other words, he did experience the moment of anagnorisis that is central to the effectiveness of any tragedy. In the final months of his life he registered time and again a sense of failure, failure of the mission he had set himself to act as an 'agitador de espíritus' for Spain's people. As we saw from his earlier comments to the audience at King's College and however hubristic it seems, he blamed himself for the problems in Spain, 'no hemos sabido asomarnos al alma de la mocedad española'. Later that year he again pointed the finger of culpability at himself in a letter to "un "Socialista de buena fe" ' that found its way into a Venezuelan newspaper in early January 1937:

He llorado, porque a mi país alcanza una desgracia inmensa. España enrojece y la sangre corre; ¿y sabe usted lo que esto significa? Significa que en cada hogar de España anida la angustia y el dolor. Y yo que creía trabajar por la salud de mi pueblo, llevo también sobre mí la responsabilidad de esta catástrofe. Yo era de los que querían salvar al género humano sin conocer al hombre. ${ }^{44}$

Time and again at this period, as if he were a secular preacher, his mind returns to the question of reaching the souls of his audience through what he writes. The previous year when rereading Larra, he had praised his illustrious forebear for being able to 'coger a cada uno de [sus lectores] y decirle a solas lo que no cabría decirles en agrupación. Cuando nuestro objeto, nuestro fin y no nuestro medio es decir la verdad, debemos decírsela a cada uno a solas'. ${ }^{45}$ He clearly felt that he had failed to do so. What also emerges from this extract is his vivid evocation of how war is actually experienced by those it affects: 'en cada hogar de España anida la angustia y el dolor'. Before modern sensibilities or the benefit of hindsight tempt us into swift condemnation of Unamuno's mistakes, we ought to bear his words in mind. The Spain of early 1936, a country in which social order was breaking

43 Quoted in Elías Díaz, Revisión de Unamuno. Análisis crítico de su pensamiento político (Madrid: Tecnos, 1968), 131.

44 Mezquita, La política, 390.

45 Unamuno, Obras completas, ed. García Blanco, III: Nuevos ensayos (1968), 1043-44. 
down, must have been a terrifying place to be, irrespective of which political group bore most responsibility for the breakdown.

One of Unamuno's final public statements was a manifesto written some time between 23 October and 21 November 1936 in which he claimed that his support for Franco was a necessary corrective to

Las inauditas salvajadas de las hordas marxistas, rojas, [que] exceden toda descripción y he de ahorrarme retórica barata. Y dan el tono no socialistas, ni comunistas, ni sindicalistas, ni anarquistas, sino bandas de malhechores degenerados, expresidiarios criminales natos sin ideología alguna. ${ }^{46}$

A truth that may be unpalatable to many in Spain who are currently engaged in rewriting the history of the Second Republic is that its failure to control the anarchist hordes who burnt down churches and fought pitched battles with the authorities in the streets of Madrid was a frightening spectacle to as seasoned a campaigner as Unamuno; as Tasende has commented on the essays he wrote in that period:

Unamuno culpa una y otra vez al gobierno republicano de incurrir en toda suerte de excesos, de no estar formando una fe y una conciencia nacional, de no estar fraguando una fe y una esperanza y un destino, de haber perdido el sentido histórico y de haber olvidado la misión de España en el mundo. ${ }^{47}$

We can see this theme reappear in the comments Unamuno makes concerning King Henry VI in El resentimiento. We ought to note to begin with that Henry VI dramatizes the Wars of the Roses, civil conflict precipitated by the conflicting claims to the English crown of Henry VI and Richard, Duke of York. It does not seem precipitous to conclude that Unamuno was drawn back to these plays in search of answers to the question of why brother should turn against brother. The political situations in Spain and Shakespeare's play could, on the face of it, scarcely be more contrasting. And yet, we might speculate whether Unamuno saw in the ponderous, indecisive King Henry VI a foreshadowing of Manuel Azaña, President of the Second Republic, at whose door he placed much of the blame for the country's current predicament: ${ }^{48}$ he even went so far as to suggest that Azaña should

46 Manuel María Urrutia, 'Un documento excepcional: el manifiesto de Unamuno a finales de octubre-principios de noviembre de 1936', Revista de Hispanismo Filosófico, 3 (1998), 95-101 (p. 100).

47 Tasende, 'El resentimiento trágico de la vida: últimas reflexiones', 281.

48 An eyewitness to the outbreak of the Spanish Civil War, the Daily Telegraph correspondent Henry Buckley, wrote of his disappointment at Azaña's ponderous and uninspired political style. Following a mass rally in November 1935 at which 200,000 people were present, Buckley claimed that 'la gente regresó a sus hogares con las manos 
commit suicide as an act of patriotism. ${ }^{49}$ With the exception of King Richard $I I I$, which deals directly with the rise of a tyrant, all of the Shakespeare plays Unamuno re-read in his final months examine questions of good government, the three parts of King Henry VI, King Lear and The Tempest certainly do, as we have already seen, while King Richard II could be called his most affecting portrait of an injudicious leader.

Of the three parts of Henry VI, the second seems to have made the most lasting impression on Unamuno, judging both by his remarks in $E l$ resentimiento and the extensive annotations he made in the margin of his edition. His comments in El resentimiento are not as expressive as we might like. However, when we examine them alongside his annotations, their meaning appears clearer:

This Gloucester should be quickly rid the / world - to rid us from the fear we have of / him (echarle del mundo para echar fuera / el miedo etc) Second Part of King Henry / VI Dice la reina Margarita act III scene 1 / Margarita v. 3a parte I 4 / Ferocidades de las tres partes del rey / Henry VI Jack Cade etc loba de Francia / El resentimiento trágico de / la vida. ${ }^{50}$

By quoting Queen Margaret's words on the subject of Gloucester, Unamuno is perhaps alluding to the tendency in Spain no longer to listen to one's enemies, rather to seek their instant demise. He remarks on the 'Ferocidades' in each play, and specifically on Jack Cade, the 'Kentish man' employed by the Duke of York to whip up rebellion in the kingdom. Examination of Unamuno's edition reveals that he had marked most of Cade's significant speeches in 4.2 and 4.7 with his usual ' $T$ '-shaped marginal annotations. A. D. Nuttall singles out the Cade scenes in Henry VI, calling them significant dramatic 'islands', while also drawing attention to the fact that Cade is a communist avant la lettre:

[...] he believes in the abolition of private property [...] Cade is a grotesque, half-comic threat to all around him and deserves to be crushed. His henchman's line, 'The first thing we do, let's kill all the lawyers' (IV.ii.6-7), must always, I suspect, have got a laugh and a sputtering of applause from some in the audience. Yet there is no serious

vacías. Ya no les [sic] quedaba un resquicio de esperanza para creer que las cosas cambiarían, que sus hijos irían a la escuela y que incluso llegarían a ir a la universidad, que habitarían en viviendas dignas y no en las chabolas que ahora ocupaban. Y aquella falta de esperanza en un futuro mejor traería consigo la violencia, disparos contra la Guardia Civil, incendios de iglesias'. See his Vida y muerte de la República española, trans. Ramón Buckley (Madrid: Espasa-Calpe, 2004), 152.

49 Mezquita, La política, 394.

50 Miguel de Unamuno, El resentimiento trágico de la vida. Notas sobre la revolución y guerra civil españolas, ed. Carlos Feal (Madrid: Alianza, 1991), 37. 
doubt that a society without law is a kind of horror, a jungle of random suffering and unchecked aggression. ${ }^{51}$

We need only add that Unamuno had indeed marked those lines in his edition and that he did not need to engage an effort of the imagination to know that the world of anarchy Cade represents is one full of horror. He wishes to create a world in which there will be no money and all shall worship him. He and his followers deliver summary justice to any educated people they come across, among them a clerk who is thought by them to have 'confessed' to a crime when he admits that he can write his name. ${ }^{52}$ A like punishment is meted out to Lord Saye whom Cade harangues in a mock trial, another of the passages Unamuno had marked in his edition of the play:

Thou hast most traitrously corrupted the youth of the realm in erecting a grammar school; and, whereas before our forefathers had no other books but the score and the tally, thou hast caused printing to be used and, contrary to the King, his crown and dignity, thou hast built a paper-mill. It will be proved of to thy face that thou hast men about thee that usually talk of a noun and a verb, and such abominable words as no Christian ear can endure to hear. ${ }^{53}$

Testimony to the Basque writer's efforts at comprehension of Cade's speeches are the underlined words of unfamiliar vocabulary in his edition. For example, in the speech just quoted Unamuno sought clarification of the precise terms used by Cade in his comparison of good 'honest' trade practices, 'the score and the tally' system so basic it could be understood by the most rustic peasant, with the underhand use of written language, in his mind a system devised by the privileged to cheat the poor. Thus Unamuno had underlined the words 'score' and 'tally', writing next to the former 'talla, incisión' and to the latter 'palo en que se marcaba'. Hatred of the educated was a trait Unamuno likewise recorded in El resentimiento, where he alludes to the 'Odio a la inteligencia' that seems to underlie much of the ire displayed by anarchist crowds. He told one journalist that the government in Madrid represented 'la anarquía, con todos los atributos que esta palabra temible supone. Alegre anarquismo, lleno de cráneos y huesos de tibias y destrucción'. ${ }^{54}$ Clearly what resonated with him most in King Henry VI was Shakespeare's ability to capture the thought patterns of the resentful rabble in the face of authority. According to Jonathan Bate, Cade's rebellion

51 A. D. Nuttall, Shakespeare the Thinker (London: Yale U. P., 2007), 44.

52 William Shakespeare, King Henry VI, Part Two, ed., with an intro., by Ronald Knowles (London: Arden, 1999), 4.2.93-99.

53 Shakespeare, King Henry VI, Part Two, ed. Knowles, 4.7.29-37.

54 Mezquita, La política, 393. 
was among Shakespeare's first significant achievements as a dramatist 'for [the] introduction into publicly staged drama of the common crowd' ${ }^{55}$

Unamuno clearly also believed that the anarchism and civil disorder that had overtaken Spain in the final months of the Republic were a product of what he alternately termed 'desesperación' and 'resentimiento'. Still adhering to what look now like outmoded thought patterns, he insisted that the anarchist hordes were driven by a resentment born out of a sense of the existential absurd: because they could believe in nothing, they let out their frustrations on the institutions that had failed to fill the void: "iQueman las iglesias por desesperación! Están desesperados de no creer en nada' ${ }^{56}$ A further reference to King Henry VI and King Richard III, demonstrates that he was finding in Shakespeare a confirmation of this developing thought:

El domingo 13 de set. cuando se hablada [sic] próxima / toma SS [San Sebastián] y se comentaba ruina de Irún acababa / de leer el Rey Enrique VI de Shakespeare con lo / de Jack Cade y empecé a leer la terrible tragedia / de Ricardo III el estigmático. Aquella entrada, la / honda descripción del resentimiento trágico fun- / dado en miseria corporal. Y la espiritual? La de- / formidad mental de un pueblo? ${ }^{57}$

It could well have surfaced once again a month later in the 'paraninfo' at Salamanca, when Millán Astray is reported to have cried out "iMuera la inteligencia!' during his altercation with Unamuno. In his reply Unamuno allegedly referred in none too flattering terms to his interlocutor's mutilated body (Astray had lost both an arm and an eye fighting in Spain's colonial wars in North Africa), picking up this same thread of argument and linking character traits to physical handicaps. Astray was thus an incarnation of Shakespeare's Richard III inasmuch as his deformed body was the outer manifestation of a twisted soul. And it was also this line of thinking that helped him to rationalize his enduring faith in Franco himself since he could trace the unpalatable views of his close collaborator to personal rather than ideological roots and leave the Nationalist leader unbesmirched. ${ }^{58}$ It is worth adding that, taken alongside the 'odio a la inteligencia' Unamuno perceived among the crowds on the nation's streets, Astray's outburst must have underlined for him what little those armed only with patience and rational argument could achieve in so polarized a climate.

55 Jonathan Bate, The Genius of Shakespeare (London: Picador, 1997), 109.

56 Mezquita, La política, 392.

57 Unamuno, El resentimiento, ed. Feal, 37.

58 Trapiello points out that Unamuno was far from unique in regarding Franco as a cut above his fellow army officers: 'En 1936 Franco era lo que se sabía de él, un militar con una trayectoria no más irregular que la de muchos otros militares republicanos y con un historial bélico prestigioso en las guerras africanas'. See Las armas y las letras, 329. 
The final reference to Shakespeare in El resentimiento is to The Tragedy of King Richard II, a play which offers at first sight so many rich parallels with Unamuno's situation that it is tempting to pursue them for their own sake. Applicable to his life's experiences in the first two Acts alone are Mowbray's moving lament to his mother tongue on being exiled for life by the flailing Richard II: 'Within my mouth you have engaoled my tongue, / Doubly portcullised with my teeth and lips, / And dull unfeeling Ignorance / Is made gaoler to attend on me'; or Bolingbroke's reflection shortly afterwards as the King cuts his banishment from ten to six years: 'How long a time lies in one little word! / Four lagging winters and four wanton springs / End in a word; such is the breath of kings' ${ }^{59}$ It is difficult to imagine that the Unamuno who had suffered for so long at the hands of a weak sovereign did not read these words with a sense of empathy. Looking at his situation retrospectively as we have been doing, it is similarly tempting to apply to him John of Gaunt's bitter-sweet reflection that dying men often attract the undivided attention of those around them precisely at a time when it can do them least good:

$\mathrm{O}$, but they say the tongues of dying men / Enforce attention like deep harmony. / Where words are scarce, they are seldom spent in vain, / For they breathe truth that breathe their words in pain. / He that hath no more must say is listened to more / Than they whom youth and ease have taught to glose. More are men's ends marked than their lives before. ${ }^{60}$

However, he marked none of these passages. Instead he highlighted others that we might see in the context of his attempts to negotiate a complex public role at this fratricidal juncture. King Richard II's opening exchanges present the dispute between Mowbray and Bolingbroke (later Henry IV), the future usurper of the throne, during which the former demands satisfaction for the slander the latter has made against him, on the basis that 'The purest treasure mortal times afford / Is spotless reputation; that away, / Men are but gilded loam or painted clay'. ${ }^{61}$ Did he underline this passage conscious that his own reputation hung in the balance of posterity? When taken together with the next passage to which Unamuno drew attention it is possible to see that he was conscious of the play's sophisticated interrogation of the concept of public duty. That passage is the Duchess of Gloucester's rebuke to her brother-in-law John of Gaunt for his reluctance to seek justice for the death of his brother the Duke of Gloucester. Central to her argument is the idea that in fraught times it is the duty of high-born men to stand up for what is right: 'That which in mean men we entitle patience / Is pale cowardice in noble breasts' ${ }^{62}$

59 William Shakespeare, King Richard II, ed., with an intro., by Charles R. Forker (London: Arden, 2005), 1.3.166-69, 1.3. 213-15.

60 Shakespeare, King Richard II, ed. Forker, 2.1.5-11.

61 Shakespeare, King Richard II, ed. Forker, 1.1.177-79.

62 Shakespeare, King Richard II, ed. Forker, 1.2.33-34. 
In actual fact, Unamuno's allusion to 'Rey Ricardo II' comes at a point in El resentimiento when he is apparently contemplating the difficulty of his public role:

Guerra de irreligión. / Complejo de inferioridad infantil. / Los caciques parados. / No se puede ni ir a dar el pésame a todos ni a protestar, ni a responder. / Rey Ricardo II. Espléndida retórica de Shakespeare. ¿Pero esta? ${ }^{63}$

Although the allusion is both fleeting and compressed, 'no se puede ni ir a dar el pésame a todos ni a protestar, ni a responder', the allusion to Richard II could be a continuation of that train of thought: that one man can only do so much to right the wrongs of an entire state. Unsatisfactory as it seems to have to couch my conclusions in the conditional mode, any more definite presentation of them would be dishonest. At the same time, merely taking his words at face value and recording that he found the rhetoric of Richard II splendid is not especially illuminating. Wringing any greater sense from these words requires us to enter into more speculative territory, based on his annotations of the play. As a starting point it is worth pointing out that 'Rey Ricardo II' leaves unclear whether he is referring to the King himself or the play as a whole. And that ambiguity is heightened still further when a perusal of his annotations reveals that of the thirteen passages he marked, no fewer than eight (and all of the passages after Act 2) are speeches by the departing King. That shift in emphasis is perhaps not surprising given that Shakespeare's text invites the reader to perform a complete volte face in his or her interpretation of the monarch: from a weak, capricious and foppish figure, Richard's conduct changes to that of a wronged but dignified sovereign invested with all of the gravitas of his divine right to rule. Thus here are some of the passages Unamuno marked:

I had forgot myself. Am I not king? / Awake, thou coward Majesty, thou sleepest! (3.2.87)

And nothing can we call our own but death (3.2.152)

What must the King do now? Must he submit? / The King shall do it. Must he be deposed? / The King shall be contented. Must he lose / the name of King? I'God's name, let it go. (3.3.143-46)

My crown I am, but still my griefs are mine. / You may my glories and my state depose, / But not my griefs; still am I king of those. (4.1.191-93)

They shall be satisfied. I'll read enough / When I do see the very book indeed / Where all my sins are writ, and that's myself. (4.1.273-75)

63 Unamuno, El resentimiento, ed. Feal, 31. 
'Tis very true, my grief lies all within (4.1.295)

The pathos elicited for the departing Richard is focused on his essential humanity, as he recognizes the frailties that have contributed to his own downfall. Hence the play encourages the audience to consider the mystery of a divine order, the crown, embodied by an imperfect human agent. When Unamuno responded in his final months to the 'espléndida retórica' of the play, I wonder whether he did so because of the lucidity with which Shakespeare is able to explore that mystery; a lucidity that must have contrasted heavily with the polarized harangues - ¿Pero esta?'- that now passed for political discourse in the Spain of 1936.

In drawing this discussion to a close, it remains only to say that, rather than castigate Unamuno as a late-flowering fascist, we might extend our sympathy to someone who had simply got it wrong. That he spent so much time in his final months grappling with Spain's problems, thinking them through with Shakespeare as his guide, has shown how unenviable the choices he felt forced to make were. Until the final months of 1936, he continued to believe that Franco was engaged in a fight for 'la civilización occidental cristiana'. He likewise believed that Franco and Mola represented the moderate faction among the Nationalist Generals. It was only in December that he finally accepted that the war had become a fratricide on a far wider scale than he could have imagined and that Franco was looking for vengeance not moderation. ${ }^{64}$ Two of the final known photographs of him capture the essence of his dilemma. The first is the famous image of Unamuno leaving the 'paraninfo' and being ushered into a waiting car in the midst of a mass of Falangists and soldiers with their arms raised in an aggressive fascist salute. The second is of Unamuno's coffin emerging from the door of his home on the Calle de Bordadores into a crowd no smaller in size but considerably calmer in demeanour. The four pall-bearers are all members of the Falange ${ }^{65}$ while among the crowd a smattering of hands are raised in fascist salute, presaging 'el entierro con que los falangistas le despidieron de este mundo en medio de gritos fascistas y saludos romanos'. A burial that, in the light of Unamuno's true opinions of the Falange, Tasende calls 'indignante'. ${ }^{66}$ Perhaps the sorry saga is best summed up by the poet Antonio Machado, another of the bright stars of the age who was to lose his life during the war, 'Señalemos hoy que Unamuno ha muerto repentinamente, como el que muere en guerra. ¿Contra quién? Quizás contra sí mismo'. ${ }^{67}$

64 Urrutia, 'Un documento excepcional', 101; Mezquita, La política, 411.

65 Rabaté, Miguel de Unamuno: biografía, 703-04.

66 Tasende, 'El resentimiento trágico de la vida: últimas reflexiones', 292.

67 Antonio Machado, Poesía y prosa, ed., with intro., by Oreste Macrì, 4 vols (Madrid: Espasa-Calpe, 1989), IV: Prosas completas (1936-1939), 2182. 